\title{
PURPURA AND INTUSSUSCEPTION
}

\author{
BY \\ H. WOLFSOHN, M.D., M.R.C.P., D.C.H. \\ (From the Fulham Hospital, London)
}

As early as 1808 Willan described visceral crises occurring with purpura. Henoch published his classical paper in 1874, after which date abdominal purpura became associated with his name. The first report of intussusception with purpura appears to have been that of Vierhuff (1893). Since then, as far as can be ascertained, this combination has been reported only nineteen times. It is for this reason and because of the many interesting points this conclition raises that a further case is recorded.

\section{Case Report}

A male child aged four years and eight months was admitted to hospital on Nov. 12, 1946. A month earlier he had had an attack of abdominal pain and vomiting which subsided rapidly and which was labelled ' chill on the liver.' Otherwise his earlier childhood had been uneventful except for measles, whooping cough, and tonsillitis. He was an only child. Both his parents were healthy and had not suffered from any of the allergic diseases.

Four days before admission he complained of pain in his left knee and the mother noticed that there was much swelling. The next day his right elbow became swollen and painful. He was then taken to his doctor, who diagnosed rheumatic fever and prescribed sodium salicylate. On Nov. 12 the swelling of his left knee had subsided but his right elbow and right wrist were painful. At noon on this day he suddenly developed severe abdominal pain, which was soon followed by vomiting. At the same time purpuric spots were observed on buttocks and right arm and he was transferred to hospital as a possible case of Henoch's purpura. His bowels had been regular until then, and no blood was noticed in the stool passed that morning.

On examination he was found to be normally developed and thin. He was apyrexial and quite alert. His skin was of striking pallor, but the conjunctival mucosa was well coloured.

Joints. He complained of no pain in the joints, and all movements were unrestricted and painless. There was some swelling of his right elbow, and possibly also of the right wrist.

Rash. A crop of petechial haemorrhages was found on his buttocks which, according to the mother, had been larger and more distinct a few hours previously. On the outer side of the swollen right elbow he had an extensive ecchymosis, and in the right cubital fossa there was one definite purpuric spot. He also had a boil on his right thigh. No urticarial lesions were seen.

Abdomen. Liver and spleen were not palpable. In the right iliac fossa a hard irregular mass was falt which was very slightly tender. It could $b$ z readily moved up and down but less easily sideways. It appeared to be in the peritoneal cavity. It occupied most of the right iliac fossa. A knob on its outer side was attached to the main mass. On rectal examination semi-solid yellow faeces without blood were found, and no other abnormality was detected. Cardiomuscular, respiratory, lymphatic, and central nervous systems appeared normal.

INVESTIGATIONS. The Mantoux test, 1-10,000, was negative. Red blood cells numbered $6,180,000$ per c.mm. of blood; haemoglobin was 120 per cent., colour index 0.9 , white cells 18,100 per c.mm., polymorphs 76 per cent., lymphocytes 20 per cent., monocytes 4 per cent., and blood platelets 238,000 per c.mm.

There was a trace of albumin in the urine; no red blood cells were seen. Culture was sterile, and there was a yellow reduction of Benedict's solution.

Bleeding time was $2 \frac{1}{2}$ minutes, coagulation time $3 \frac{3}{4}$ minutes, and the tourniquet test negative.

A tentative diagnosis of purpura with rheumatic (Schönlein's) and abdominal (Henoch's) symptoms was made, but in view of the abdominal mass the possibility of intussusception could not be excluded.

Progress. On Nov. 13 he vomited watery fluid once during the night. He had no appetite and became more dehydrated. The abdominal lump could still be felt. Intravenous therapy (glucose saline and plasma) was begun. Next day he was still vomiting and the petechiae were paler. At the advice of the paediatric consultant, expectant treatment was continued.

On Nov. 15 his general condition had deteriorated, anorexia, vomiting, and dehydration being marked. There had been no bowel action since admission. The cardiac rate was now 150 per minute, although temperature was still normal. The vomit contained upper intestinal contents. The abdomen was more distended; and the lump, unchanged in size and shape, was slightly more tender. Purpura was still 
present but only very faintly. In.spite of dehydration there was now frequency of micturition and the urine gave an orange reaction to Benedict's solution and contained ketone bodies. Capillary blood sugar at 4 p.m. was $313 \mathrm{mg}$. per cent. The occurrence of diabetic symptoms was considered to be due to a temporary toxic exhaustion of islet function.

As conservative measures, continued over three days, had not resulted in any improvement, as the abdominal mass had remained unchanged during the time of observation, and as the child had become extremely ill from acute intestinal obstruction, laparotomy was decided on. The intravenous drip was carried on throughout the operation and during the next two days. Penicillin (15,000 units every three hours) was given intramuscularly, and soluble insulin in doses of twenty units at 4 p.m., at 5.30 p.m., and again at 7 a.m. the next day, when his urine still gave a green reaction to Benedict's solution.

OPERATION. At operation (under nitrous oxide and ether anaesthesia) blood-stained fluid appeared when the peritoneum was opened. An irreducible ileo-ileal intussusception was found, with its apex about six inches from the ileo-caecal valves. This was resected from four inches above to two inches below the intussusception and a side-to-side anastomosis performed to restore the continuity of the gut. Rapid examination of the peritoneal contents showed no purpuric haemorrhages. The wound was closed in layers. The removed specimen consisted of about eight inches of intussuscepted small intestine causing haemorrhagic infarction.

On Nov. 16 the general condition was much better. The pulse was full and good, and there was no further vomiting. At 3.30 p.m. the child became suddenly worse and failed to respond to questions. He was unable to swallow and had a squint and a right plantar extensor response. As this attack occurred so rapidly, and more than eight hours after his last dose of soluble insulin, it was not considered to be due to hypoglycaemia, particularly as his intravenous glucose saline infusion was still in progress. The blood sugar was, however, not examined. The possibility of a purpuric intracerebral haemorrhage was dismissed as unlikely. The attack was probably due to a small cerebral embolus. On the next day he was gradually regaining consciousness, and by Nov. 18 was fully conscious, talking, and swallowing well, with no abnormal neurological signs. At this and subsequent examinations there were no reducing substances in the urine. The temperature was $100^{\circ} \mathrm{F}$., and there was pneumonic consolidation in the right upper lobe. Sulphadiazine was begun in addition to penicillin, and the intravenous drip discontinued.

On Nov. 20 the chest was beginning to clear, the abdomen was soft, and the temperature $99^{\circ} \mathrm{F}$. There was pain and swelling in both wrists and the left elbow, but no rash. Sodium salicylate, gr. 15 four-hourly, was begun. By Nov. 23 the pains and swelling in the joints had subsided, but there were petechial spots on both elbows. He vomited after taking salicylate, so this was changed to aspirin tablets and to calcium aspirin gr. 10, three times a day. Sulphadiazine was discontinued.

On Nov. 24 the rash round the elbows had become more profuse. Some spots were truly petechial, others were raised. At night the temperature was still $99^{\circ}$ F. By Nov. 25 there was swelling and bruising of the right metacarpo-phalangeal joint of the right thumb, with recurrence of swelling of right wrist and dorsum of the right hand. There was more purpura also on the left elbow, but no other petechiae were seen. The chest was now clinically clear, and penicillin and all salicylates were stopped. He was afebrile.

On Nov. 29 he complained of abdominal pain and pain in the right lower chest. There were no abnormal signs. On Dec. 11 a swelling appeared over left tempero-mandibular joint, and also over the right frontal region and in the right knee joint. The temperature had risen to $102^{\circ} \mathrm{F}$. by next morning, but gradually fell to normal by Dec. 17. The right testis was tender and slightly enlarged. A radiograph of the skull showed nothing abnormal.

By Dec. 17 he was afebrile and symptom-free, the bowels were regular, the abdomen soft, and there were no signs or symptoms in the joints and no urticarial or purpuric eruptions. The blood sedimentation rate was $40 \mathrm{~mm}$. in the first hour.

On Dec. 31 he was transferred to Queen Mary's Hospital, Carshalton. Radiography of chest, joints, and long bones revealed nothing abnormal. The blood sedimentation rate varied between $35 \mathrm{~mm}$. and $10 \mathrm{~mm}$. per hour up till the middle of March, 1947, and has been normal since then. He has had several short febrile episodes, one accompanied by abdominal pain, two by finger sepsis, and one by neck pain radiating in turn to either ear. He has received dental treatment and has had aspirin administered for several weeks. No further purpura has been noted.

In July, 1947, there was a further attack of abdominal pain, accompanied on one occasion by passage of bright red blood. There were no other purpuric manifestations, and he was symptom-free after two days.

\section{Analysis of this and Previously Reported Cases}

Sex. Of the twenty cases under review, sixteen occurred in boys. The large preponderance of boys is significant and exaggerates a similar sex irregularity found amongst patients with so-called Henoch's purpura without added complications. McKechnie (1911) in fact states that all his cases of Henoch's purpura at Vancouver occurred in boys, although other observers have described this condition also in girls. Non-purpuric intussusception also is said to be two to three times more common in males than in females (Mitchell-Nelson, 1946). The male incidence of 80 per cent. in the present series may therefore be explained by either condition alone or 
by the combination of intussusception and purpura.

Age. The average age of the twenty cases is $9 \frac{1}{2}$ years. Excluding the four adults of 21, 31, 29, and 21 , the average age of the remaining sixteen children becomes nearly six years, which is a figure very much higher than that of intussusception without purpura. Indeed not one patient was under three years old, whereas the non-purpuric intussusception occurs most commonly in young children under three. On the other hand the age distribution tallied well with that of anaphylactoid purpura generally. This fact is important and supports the supposition that purpura is the primary condition.

Symptomatology. The initial symptoms and signs described in these cases differ in no way from those of non-thrombocytopenic purpura with abdominal symptoms. Their duration before intestinal obstruction becomes manifest is very variable. Most of the children were 'not well' for a few days to a few weeks before the onset of intestinal blockage. Döbeli's (1908) patient gave the longest history. For about five years he had had abdominal and joint pains which were considered to be due to lead poisoning or rheumatism. Gara's (1912) patient suffered from ' purpura simplex' for two years before intestinal symptoms developed. At the other extreme is Gamstedt's (1933) patient, in whom only three days after the onset of symptoms an irreducible intussusception was found at laparotomy.

JoINT PAINS. In eleven out of seventeen patients joint pains and swellings were described, eighteen months to two days before the obstruction. A not unusual story is that the joint symptoms subsided rapidly with or without salicylates and that the intussusception occurred shortly afterwards. This happened in the present case and in the one reported by Robinson (1910) and Döbeli (1908).

PuRPura. Purpura in some form or other was invariably present, and indeed its presence forms part of the diagnosis. Sutherland (1909) regarded a case of Still's (1909) where no haemorrhagic manifestations were described as one of anaphylactoid purpura. Nowadays, however, we would classify this particular patient as having suffered from chronic recurrent intussusception. In this series in practically every patient some cutaneous manifestations were obvious: at times a few isolated pin-point petechiae around the elbow joints or over the buttocks, at times larger ecchymoses, were seen. Haematuria is mentioned in four of the cases. Nose bleeds and vomiting of blood were recorded only once. 'An interesting symptom, which is not usually referred to in this connexion, is pain, swelling, and sometimes discoloration of the scrotum, which are described by Lett (1908b), Lederer (1913), Tonking (1910), and in my patient.

INTUSSUSCEPTION. Of particular clinical interest and of vital importance is the diagnosis of intussusception in this condition. Sutherland. referring to intussusception and abdominal purpura, stated in 1909, 'We do not seem to possess any reliable means of distinguishing these two affections, and even now, nearly forty years later, the problem is still equally difficult. Far more patients with purpura and abdominal symptoms are suspected of intussusception and are operated on than are actually found to have this condition. Very many cases of this kind have been reported in the literature, and many more have undoubtedly occurred, for example, Bailey (1930), Burrows (1904), Sutherland (1904), FitzWilliams (1908). The most tragic of these is probably that of Sutherland's; he, having advised laparotomy on one of his patients, who turned out to have no intussusception, refrained from operating on a very similar case shortly afterwards, and the child died from peritonitis due to intestinal invagination. A similar disaster was fortunately, but only barely, avoided in my own case.

There is not one symptom which clearly differentiates the two conditions. Bailey (1930), discusses the differential diagnosis between nonpurpuric intussusception and Henoch's purpura, and Althausen et al. (1937), try to clarify the matter by tabulating the essential symptoms and signs. The younger age, abdominal tenderness disappearing between colics, absence of bleeding (haematemesis, petechiae, haematuria, and joint symptoms), and particularly the presence of a sausage shaped mass are all in favour of intussusception. None of these pointers are of course relevant to our present problem, where both phenomena are present at the same time. An abdominal mass has been felt frequently in uncomplicated purpura, and may have been due to bleeding into the intestinal wall (Greig, 1908), or lumen (FitzWilliams, 1908), to haemorrhage into the mesentery (Lett, 1908a), or omentum, to localized oedema and extravasation of fluid into these organs, to faecal masses, or even to the imagination of the observer. On the other hand, in the present series were at least six cases where no tumour was felt but the intussusception was discovered by operation (Hall, 1908; Collinson, 1910; de Lavergne, 1927), autopsy (Sutherland, 1909; Gara, 1912) or when passed per rectum (Lederer, 1913). Even vomiting was absent three times (Lett, 1908; Döbeli, 1908; Robinson, 1910). The presence or absence of blood in the stools also is of little significance. Reviewing all the cases, one can only say that a sudden worsening of the condition of a purpuric patient, if accompanied by severe colicky abdominal pain and vomiting, by absolute constipation (or the passage of bright red blood without faecal material or flatus), and by the appearance of an abdominal lump which changes little on repeated examination, should provide a strong indication for laparotomy. If this dictum is followed many children will be unnecessarily submitted to laparotomy, as has hitherto occurred. But the risk of an unnecessary operation must be very much smaller than that of leaving an intussusception untouched (Schwartzman, 1940).

All the patients in the present series have had 
TABLE OF REPORTED CASES OF PURPURA WITH INTUSSUSCEPTION

\begin{tabular}{|c|c|c|c|c|c|c|c|c|c|c|c|}
\hline $\begin{array}{c}\text { Case } \\
\text { No. }\end{array}$ & Author & $\begin{array}{l}\text { Sex and } \\
\text { Age }\end{array}$ & $\begin{array}{c}\text { Joint } \\
\text { Symptoms }\end{array}$ & Purpura & $\begin{array}{l}\text { Vomit- } \\
\text { ing }\end{array}$ & $\begin{array}{l}\text { Blood } \\
\text { p.r. }\end{array}$ & $\underset{\text { turia }}{\text { Haema- }}$ & Mass & $\begin{array}{l}\text { Site of } \\
\text { Intussus- } \\
\text { ception }\end{array}$ & Treatment & Result and Remarks \\
\hline 1 & $\begin{array}{l}\text { Vierhuff } \\
\text { (1893) }\end{array}$ & M. 29 & . & & . & + & & & Ileo-caecal. & No operation. & $\begin{array}{l}\text { Intussuscepted pieco of bowel } \\
\text { passed per rectum. } \\
\text { covery. }\end{array}$ \\
\hline $2 !$ & Lett (1906) & M. 3 & + & + & 0 & + & $\mathbf{0}$ & R. Loin. & $\begin{array}{l}\text { Ileo-caecal. } \\
\text { Ileo-ileal }\end{array}$ & $\begin{array}{l}\text { Reduced. } \\
\text { No operation. }\end{array}$ & $\begin{array}{l}\text { Recurrence of intussuscep- } \\
\text { tion three days after reduc- } \\
\text { tion of first. Died. }\end{array}$ \\
\hline 3 & Hall (1908) & M. $5 \frac{1}{2}$ & + & + & + & 0 & 0 & 0 & Ileo-ileal. & Resection. & Died. \\
\hline 4 & $\begin{array}{l}\text { Döbeli } \\
\text { (1908) }\end{array}$ & M. 8 & + & + & $\mathbf{0}$ & + & + & $\begin{array}{l}\text { Left hypo- } \\
\text { chrondrium } \\
\text { at intervals. }\end{array}$ & $\begin{array}{l}\text { ? Sigmoid } \\
\text { colon. }\end{array}$ & $\begin{array}{l}\text { Enemas of } \\
\text { glycerine and } \\
\text { oil. }\end{array}$ & $\begin{array}{l}\text { Recovered. Frequent re- } \\
\text { lapses of intestinal obstruc- } \\
\text { tion, purpura, and intestinal } \\
\text { masses. Presence of intus- } \\
\text { susception not proved. }\end{array}$ \\
\hline 5 & $\begin{array}{l}\text { Sutherland } \\
\text { (1909) }\end{array}$ & F. 7 & 0 , & + & $\begin{array}{l}\text { with } \\
\text { blood. }\end{array}$ & + & + & 0 . & Ileo-caecal. & No operation. & $\begin{array}{l}\text { Died. General peritonitis at } \\
\text { necropsy. }\end{array}$ \\
\hline 6 & $\begin{array}{l}\text { Morse and } \\
\text { Stone (1909) }\end{array}$ & F. 7 & + & + & + & + & $\mathbf{0}$ & R.I.F. & Ileo-colic. & Reduction. & $\begin{array}{l}\text { Recovery. Recurrence of } \\
\text { vomiting, purpura, intes- } \\
\text { tinal bleeding. At laparo- } \\
\text { tomy, nothing abnormal. }\end{array}$ \\
\hline 7 & $\begin{array}{l}\text { Collinson } \\
\text { (1910) }\end{array}$ & M. 4 & + & + & + & 0 & 0 & 0 & $\begin{array}{c}\text { Ileo-ileal. } \\
\bullet\end{array}$ & $\begin{array}{l}\text { Insertion of } \\
\text { Paul's tubes. }\end{array}$ & $\begin{array}{l}\text { Resection } 3 \text { days after } \\
\text { preliminary operation. } \\
\text { Recovery. }\end{array}$ \\
\hline 8 & $\begin{array}{l}\text { Tonking } \\
\text { (1910) }\end{array}$ & M. $\quad 5 \frac{1}{2}$ & + & + & + & 0 & & $\begin{array}{l}\text { Above } \\
\text { umbilicus. }\end{array}$ & lleo-ileal. & Reduction. & Recovery. \\
\hline 9 & $\begin{array}{l}\text { Robinson } \\
\text { (1910) }\end{array}$ & M. 5 & + & + & 0 & + & & $\begin{array}{l}\text { Below } \\
\text { umbilicus. }\end{array}$ & Ileo-ileal. & $\begin{array}{l}\text { Reduction } \\
\text { and resection. }\end{array}$ & $\begin{array}{l}\text { Affected bowel also resected } \\
\text { because of mesenteric throm- } \\
\text { bosis and gangrene. Re- } \\
\text { covery. }\end{array}$ \\
\hline 10 & $\begin{array}{l}\text { McKechnie } \\
\text { (1911) }\end{array}$ & M. 10 & 0 & + & + & + & + & $\begin{array}{l}\text { Right of } \\
\text { umbilicus. }\end{array}$ & Ileo-ileal. & Reduction. & $\begin{array}{l}\text { Died several months later } \\
\text { from nephritis. }\end{array}$ \\
\hline 11 & Gara (1912) & M. 5 & $\mathbf{0}$ & + & + & $\begin{array}{l}\stackrel{+}{\text { after }} \\
\text { enema. }\end{array}$ & + & $\begin{array}{l}\text { Right of } \\
\text { umbilicus. } \\
\text { Not felt } \\
\text { afterwards. }\end{array}$ & Ileo-caecal. & No operation. & Died. \\
\hline 12 & $\begin{array}{l}\text { Lederer } \\
\text { (1913) }\end{array}$ & M. 12 & + & + & + & + & $\mathbf{0}$ & $\mathbf{0}$ & $?$ & $\begin{array}{l}\text { Necrotic piece } \\
\text { passed } 5 \frac{1}{8} \text { wee } \\
\text { Recovered. }\end{array}$ & $\begin{array}{l}\text { of intussuscepted intestine } \\
\text { ks after onset of symptoms. }\end{array}$ \\
\hline 13 & $\begin{array}{l}\text { Barling } \\
(1913)\end{array}$ & M. 4 & $\mathbf{0}$ & + & + & + & & Epigastric. & Ileo-colic. & Resection. & Recovered. \\
\hline 14 & $\begin{array}{l}\text { de Lavergne } \\
\text { and } \\
\text { Guillemin } \\
(1927)\end{array}$ & M. 21 & $\mathbf{0}$ & + & + & + & $\mathbf{0}$ & 0 & Ileo-ileal. & Resection. & Died. \\
\hline 15 & $\begin{array}{l}\text { Caizergues } \\
\text { (1929) }\end{array}$ & F. 3 & , & & & & & & Ileo-ileal. & Reduction. & Recovered. \\
\hline 16 & $\begin{array}{l}\text { Ballin and } \\
\text { Morse } \\
(1930)\end{array}$ & M. 31 & + & + & + & + & & $\begin{array}{l}\text { Right of } \\
\text { umbilicus. }\end{array}$ & Ileo-caecal. & Reduction. & $\begin{array}{l}\text { Death } 3 \mathrm{t} \text { months later from } \\
\text { haematuria, nephritis, pur- } \\
\text { pura. At autopsy many } \\
\text { sub-peritoneal haemorrhages } \\
\text { leading to ulceration, per- } \\
\text { foration, and peritonitis. }\end{array}$ \\
\hline 17 & $\begin{array}{l}\text { Gamstedt } \\
\text { (1933) }\end{array}$ & F. 7 & $\mathbf{0}$ & + & + & 0 & 0 & & Ileo-ileal. & Resection. & Recovery. \\
\hline 18 & Gray (1936) & M. 21 & + & + & + & + & & + & Ileo-caecal. & Reduction. & $\begin{array}{l}\text { Recovery. Six days after } \\
\text { reduction once more devel- } \\
\text { oped signs of intestinal } \\
\text { obstruction. At operation } \\
\text { kinking of terminal ileum } \\
\text { over gangrenous patch in } \\
\text { caecum. Lateral anasto- } \\
\text { mosis performed. }\end{array}$ \\
\hline 19 & $\begin{array}{l}\text { Schwartz- } \\
\text { man }(1940)\end{array}$ & M. 3 & 0 & + & + & + & 0 & Indefinite. & Ileo-caecal. & Resection. & $\begin{array}{l}\text { Died day after operation. } \\
\text { Family history of allergy. }\end{array}$ \\
\hline 20 & $\begin{array}{r}\text { Wolfsohn } \\
(1947)\end{array}$ & M. 4 & + & + & + & 0 & 0 & R.I.F. & Ileo-ileal. & Resection. & Recovery. \\
\hline
\end{tabular}


some purpuric symptoms for a few days before the onset of intestinal obstruction. If, with the above indication, laparotomy is undertaken but no intussusception is discovered, the most likely findings will be purely those of so-called Henoch's purpura. According to Holubec (1935), this may be complicated by duodenal perforation or appendicitis, and either of these may therefore have given rise to the serious symptoms. Alternatives, particularly in the slightly older age group may be what Sheppard Siegal (1945) describes as benign paroxysmal peritonitis, where a reversible inflammatory reaction occurs in the peritoneum, jointlining, and other endothelial membranes. Some of Siegal's patients came to laparotomy. Further differential diagnoses to be considered are severe constipation, appendicitis (Holubec, 1935; Whitmore and Peterson, 1946), intestinal obstruction of other types, and acute regional ileitis (Mailer, 1938). Barnes and Duncan (1941) actually made the latter diagnosis at laparotomy, but when the abdomen was reopened ten days later no abnormality was detected and purpuric manifestations made them alter the diagnosis to one of anaphylactoid purpura.

\section{Treatment and Outcome (see table)}

Of the twenty cases under review, fifteen came to operation. Of the remainder, in two (cases 1 and 12) the piece of intussuscepted intestine sloughed away and was passed per rectum. In two (cases 5 and 11) the diagnosis was only made at necropsy, and in one (case 4) we have no absolute proof that a true invagination actually occurred. Lett's patient (case 2) had a further intussusception three days after the reduction of the first. This had to be left owing to the child's condition, and he died. Gray's patient (case 18) developed signs of obstruction six days after the reduction, and this was due to kinking of the terminal ileum over a patch of gangrenous caecum. The patient recovered after a lateral anastomosis had overcome the blockage. Case 6 had to be reopened a week after the reduction of an ileo-colic intussusception because of a recurrence of abdominal pain, vomiting, and bleeding, but no abnormality whatever was found at this second operation. Immediate resection had to be performed on seven occasions, with four resulting recoveries. In one of these (case 9) the invaginated bowel could be reduced but had to be excised owing to the presence of mesenteric thrombosis and resulting gangrene. One child had the affected loop resected three days after an initial ileotomy and he recovered (case 7). Two patients (cases 10 and 16) died several months after successful operation, one from nephritis, the other, who also had nephritis, from peritonitis due to the perforation of haemorrhagic intestinal ulcers. Altogether twelve of the twenty patients recovered and, as far as is recorded, no further recurrence of either intussusception or even purpuric symptoms occurred later than a year after the abdominal catastrophe.

\section{Discussion}

The nature of anaphylactoid purpura has been frequently discussed and the present case will throw no further light on the subject. In common with most reported cases, our patient presented no family or past history of allergic disease. No precipitating factor could be elicited to account for his illness, and no eosinophilia was encountered. At first it was thought that purpura may have been the response to the administration of salicylates, but when aspirin and salicylates were given on a third occasion during his convalescence no adverse reaction occurred. At any rate salicylates do not usually lead to this kind of purpura in susceptible subjects.

Several theories have been advanced to explain why intussusception should occur in these patients. The first assumption is that purpura and intussusception occur independently, and that each happens without being influenced by the other. Against this view must be held the rarity of each of the two conditions, so that the chances of a simultaneous occurrence of both must be infinitesimally small. Furthermore, the age incid- ence of intussusception in the present series is significantly higher than is found with non-purpuric cases. This argument can be used also against the second possibility, that intussusception is the primary condition and that purpura follows as a secondary, presumably toxic, complication. Döbeli (1908) believed that a gastro-intestinal disorder, such as peptic ulceration, intussusception, or enteritis, could be found in most cases if looked for, and that through absorption of bacteria or toxins abdominal purpura resulted. He stated that only by dealing with the underlying disorder could purpura be cured. All the data, however, speak against this idea. In practically every one of the twenty cases in this series there was a clear onset of intestinal obstruction, and this was invariably preceded (and not followed) by evidence of purpura. In my own patient rheumatic symptoms and petechiae occurred three and one days before severe abdominal pain and vomiting developed. During convalescence this boy had several bouts of purpura but intussusception apparently did not recur. Even in the case described by Döbeli himself, haemorrhagic manifestations appeared some time before the onset of abdominal pain and masses, and his diagnosis of chronic recurrent intussusception of the sigmoid flexure was never proved. His may well have been a case of purely abdominal purpura. Moreover, Döbeli's theory fails to explain the great frequency of the intestinal diseases he mentions without the co-existence of purpura.

This leaves the third and most likely possibility that intussusception develops as a complication of purpura. It has been assumed that a blood clot in the bowel lumen may act mechanically by its weight and thus cause this portion to be invaginated. This seems an inadequate explanation. Hall (1908), thought that the straining from vomiting during the 
gastro-intestinal crisis of Henoch's purpura could lead to intussusception, and Althausen et al. (1937) consider amongst numerous causes of intussusception the presence of spasm in the intestinal segment above a partial hold-up, this spasm corresponding to the colicky pains experienced by the patient. Most observers agree that either extravasation of serous fluid, or especially haemorrhage into the mucous, submucous, muscular or subperitoneal coats of an intestinal segment are the main precipitating factors to produce the invagination. Intense congestion would invariably ensue. The actual intussusception could thus be the result of thickening of the bowel wall from haemorrhage, oedema, and congestion, this leading to partial obstruction, and a secondary paralysis of the affected intestinal segment with spasm and overaction of the portion above it. This theory appears to fit most of the known facts and agrees with many of the operative findings.

\section{Summary}

A case of purpura with intussusception followed by resection and recovery is described, and the literature of similar cases is reviewed. The symptomatology, etiology, diagnosis, and treatment of this condition are discussed.

I am grateful for the co-operation and advice received from Mr. J. Leebody, F.R.C.S.E., the Superintendent of Fulham Hospital, and from Mr. H. L. Cochrane, F.R.C.S., who operated on my patient, and whose interest never failed. My thanks are also due to Sister Myra Collins for the continuous watch and nursing-care which contributed so largely to the patient's recovery.

REFERENCES

Althausen, T. L., Deamer, W. C. and Kerr, W. J. (1937). Ann. Surg., 106, 242.
Bailey, H. (1930). Brit. J. Surg., 18, 234.

Ballin, M. and Morse, P. F. (1930). Ann. Surg., 91, 711. Barling, S. (1913). Brit. med. J., 1, 659.

Barnes, C. G. and Duncan, G. W. (1941). Brit. J. Surg., 29, 253.

Burrows, H. (1904). Brit. J. Child. Dis., 1, 28.

Caizergues, J. F. (1929). Nourisson, 17, 99.

Collinson, F. W. (1910). Lancet, 1, 716.

Döbeli, E. (1908). Cor-Bl. Schweiz. Aerzte, 38, 201, 240, 284.

FitzWilliams, D. (1908). Rep. Soc. Study of Dis. in Childr., 8, 320.

Gamstedt, E. (1933). Acta chir. scand., 73, 280.

Gara, A. (1912). Jahrb. Kinderheilk., N.F., 76, 573.

Gray, T. (1936). Lancet, 1, 841.

Greig, D. M. (1908). Scot. med. surg. J., 22, 302.

Hall, F. de H. (1908). Lancet, 1, 1,548.

Henoch, E. (1874). Berlin Klin. Wschr., 11, 641.

Holubec, K. (1935). Zbl. Chir., 62, 2,962.

de Lavergne, V. and Guillemin, A. (1927). Rev. méd. de L'Est, 55, 1.

Lederer, R. (1913). Z. Kinderheilk. Orig., 6, 227.

Lett, H. (1908a). Brit. J. Child. Dis., 5, 343. (1908b). Rep.Soc. Study of Dis. in Childr., 8, 307.

Mailer, R. (1938). Brit. J. Surg., 25, 517.

McKechnie, R. E. (1911). Canad. med. Ass. J., 1, 1,040.

Mitchell-Nelson. Edit. W. E. Nelson (1946). Textbook of Pediatrics, Philadelphia. p. 627.

Morse, J. L. and Stone, J. S. (1909). Arch. Pediatr., 26, 287.

Robinson, H. B. (1910). Lancet, 2, 1,008.

Schwartzman, J. (1940). Arch. Pediatr., 57, 389.

Siegal, S. (1945). Ann. intern. Med., 23, 1.

Still, G. F. (1909). Common Disorders of Childhood. London. p. 122.

Sutherland, G. A. (1904). British J. Child. Dis., 1, 23. (1909). Lancet, 1, 1,817.

Tonking, J. H. (1910). Ibid., $2,802$.

Vierhuff, J. (1893). St. Petersb. med. Wschr., N.F., $10,369$.

Whitmore, W. H. and Peterson, G. M. (1946). Radio$\log y, 46,373$.

Willan, Robert (1808). Cutaneous Diseases. London. Vol. 1, p. 457. 